\title{
The history, status and teaching of Darwinian medicine in Norway
}

\author{
Iver Mysterud \\ Division of Zoology, Department of Biology, University of Oslo, P.O. Box 1050 Blindern, N-0316 Oslo, Norway \\ Telephone +47-22854794 Telefax +47-22854605 e-mail mysterud@math.uio.no
}

\begin{abstract}
SUMMARY
This paper reviews how the application of the adaptationist program in medicine - Darwinian medicine has been presented and received in Norway from the time George Williams presented his lecture in 1990, prior to the publishing of the seminal paper "The Dawn of Darwinian Medicine". These ideas found their way into textbooks in 1996, and are also evaluated for inclusion in the curricula at several Norwegian medical and nursing schools. This paper also presents how, in one of the textbooks, Darwinian medicine is integrated into an ecological health theory within the framework of human-environment interaction.
\end{abstract}

\section{INTRODUCTION}

The term "Darwinian medicine" - the application of the adaptationist program (Mayr 1983) to medicine was coined by evolutionary biologist George C. Williams and psychiatrist Randolph M. Nesse in 1991 (Williams \& Nesse 1991). Their review of medical phenomena viewed in light of modern evolutionary theory, received a wealth of attention and stimulated a variety of research. Preceding Williams and Nesse, several pioneers in biology, medicine and anthropology had, more or less independently, conducted research based on the adaptationist program. In 1991, a common name was devised, and their common platform defined. Nesse \& Williams expanded their article into a book in 1995 (Nesse \& Williams 1995), which, together with several other books and papers (e.g. Kluger 1991, Ewald 1994, Profet 1995), spread these ideas to an ever increasing number of people. In Norway, these ideas were immediately appreciated and presented to the Norwegian medical community. Some years later, they were included in medical and nursing textbooks and were considered for inclusion in medical curricula at several universities and other centers for higher education in Norway. This paper presents a first overview of the short historical development of Darwinian medicine and its current status in Norway. It also explains how these ideas can be integrated into a more comprehensive ecological health theory.

\section{HISTORY MATTERS!}

Evolution is full of incidents which turn out to have great consequences, and evolutionists know that historical factors may be of utmost importance for future developments (e.g. Gould 1989). The seed of evolutionary ideas in medicine and its applications in Norway was sown when my father, biologist Ivar Mysterud, attended a conference on evolutionary ethics at the Chicago Museum of Natural History in May 1990, and heard a lecture given by George C. Williams. Williams was invited to Norway and the University of Oslo at his next roundtrip in Scandinavia in October 1990. He gave a lecture at the Department of Biology on "The Dawn of Darwinian Medicine" (Williams \& Nesse 1991). I was working on my Master of Science thesis at that time, and with a general interest in medicine, it was not difficult to become motivated to attempt a wider application of the adaptationist thinking in medicine. And it struck me: Why had no one previously thought of this in a systematical way?

Sponsored by the Norwegian pharmaceutical firm Hafslund Nycomed, and with a mind boiling with enthusiasm, I attended the annual meeting of the American Association for the Advancement of Science in Boston in February 1993. This was the first conference at which biologists, anthropologists and physicians with common interests in evolution and medicine was brought together. This started my "career" as a science writer and advocate of Darwinian medicine (cf. Appendix).

\section{OVERVIEW PAPERS, INTERVIEWS AND BOOK REVIEWS}

Tidsskrift for Den norske Lageforening (Tidsskr Nor Lageforen $)^{1}$ has published several overview papers, conference reports, interviews and book reviews about Darwinian medicine (Appendix). The papers have among other things presented Profet's work on allergy (1991), pregnancy sickness $(1988,1992,1995)$ and menstruation (1993), Strassman's (1996) critic of

\footnotetext{
Tidsskr Nor Lageforen (The Journal of the Norwegian Medical Association) is the leading medical journal in Norway. It is published every tenth day and has a circulation of approximately 18600 (April 1997). Approximately 16000 copies are sent to practicing and retired physicians and medical students, while 2500 are sent to ordinary subscribers. About 99.9 percent of Norway's physicians are members of The Norwegian Medical Association (Anders Taraldset, personal correspondence 1997). Tidsskr Nor Lageforen is therefore a journal which ties Norwegian physicians together.
} 
Profet's menstruation paper, Haig's work (1992, 1993, 1994) on genetic conflicts in pregnancy, and Eaton's work on which diet and physical exercise is "natural" for humans, as well as women's reproductive cancers as caused by a mismatch between human design and our new environments (e.g. Eaton et al. 1988a,b, 1994). Finally, Tidsskr Nor Lageforen has printed several reviews of books dealing with Darwinian medicine (and the general evolutionary approach) (Toft et al. 1991, Ewald 1994, Nesse \& Williams 1995, Profet 1995, Sulloway 1996).

Readers of Tidsskr Nor Lageforen have thus been exposed to a multitude of hypotheses which are debated by researchers, together with perspectives in the adaptationist program (e.g. the controversy between Profet (1993) and Strassmann (1996) about the function of menstruation). Leading proponents of Darwinian medicine (Nesse, Eaton) have been profiled in interviews, and several important books and the major research society ("Human Behavior and Evolution Society" is the major professional society for those studying humans and modern evolutionary theory) and its annual meetings have been presented.

\section{NEW COMPREHENSION OF WHAT IT MEANS TO BE A PHYSICIAN}

Shortly after the first presentations of Darwinian medicine in Norwegian journals, a short paper by the physician Merete Steen (1993) appeared in Tidsskr Nor Lageforen. Steen had "rediscovered" the healthy human body and appreciated the usefulness of viewing ourselves as evolutionary products of past interactions with the environment. She expressed that in her practice she had become too focused on the diseased body at the expense of understanding how the body's design enhanced survival when threatened. In her clinical work, many of these defenses were treated as "enemies" which were to be fought. The Darwinian perspective gave her a better understanding of our physiological potential to cope with various environmental threats. Steen specifically stated that the view of our species as "old" in a "new" environment (e.g. Eaton et al. 1988a,b), was very useful when trying to understand the human condition in the industrialized world with accelerating environmental problems. She could not remember having been taught any of this during her medical education (completed 15 years earlier). She now greatly appreciates the evolutionary perspective when teaching nursing students at the Diaconia College of Nursing in Oslo.

I believe that Steen's (1993) reactions are typical of many physicians, especially general practitioners, when confronted with the evolutionary perspective.

\section{LECTURING}

During my early advocacy of Darwinian medicine in Norway, I have held lectures for various audiences, in- cluding general practitioners, psychiatrists, university physicians, special groups of physicians interested in philosophy, ecology, environmental problems and alternative medicine, nurses, and homeopaths. Without exception, the evolutionary perspective is met with great interest and sometimes enthusiasm. I have never experienced any hostility, which might have been expected in the aftermath of the "sociobiology debate" of the 1970s and 80s, when the evolutionary approach in general was discredited in many social environments, including Norway. This may either reflect that the medical and health care environments have to a lesser degree felt threatened by sociobiology, or that the general atmosphere is not so hostile towards these ideas in the 1990s. It is my experience that medical personnel immediately grasp the value of the evolutionary approach, even though they may be reluctant to accept the various hypotheses (which is a sound attitude since Darwinian medicine is in its infancy).

\section{EVOLUTION AND EDUCATION}

The evolutionary perspective has wide implications for the education of physicians and health care personnel, as stressed by Nesse \& Williams $(1995,1997)$ and Nesse (in prep.). The remaining question is how and when this perspective can be integrated in the curricula. I argue that the evolutionary apprach should be presented to the students early on in their basic education. This would give them a framework and perspective for integrating various physiological (proximate) details. I also argue that this should be done for all subprofessions: medicine, nursing, physiotherapy, as well as within the best organized parts of so-called alternative medicine (acupuncture, homeopathy etc.). This will join personnel from various health professions in a common framework, and the basic common terminology would hopefully ease communication between the biomedical and alternative approaches.

Nesse \& Williams (1997) state that few medical schools in the USA devote even one hour to the study of how the human body evolved from our ancestors. The same has been true in Norway up until recently, with the exception of the comparative anatomy course used in the curriculum at one medical school (Oslo). It disappeared in the mid-70's (Per A. Brodal, personal communication 1997). However, when the medical curriculum in Oslo was revised in 1996, some evolutionary aspects were integrated into the first and second semesters. Actually, part of the overall goal of the first semester is to teach students how "briefly to be able to explain human beings' position in the animal kingdom, and which forces lead to change of species over time." Since 1995, medical students in Trondheim, on the third day of their first semester, have been exposed to a two-hour lecture on evolution (Olbjørn Klepp, personal correspondence 1997).

By omitting the evolutionary perspective, a major part of basic science and valuable insights is lost from 
the medical curriculum. Nesse \& Williams (1997) argue further that the basic fundamentals necessary for practicing medicine could probably be taught in 15-20 classroom hours, and that such an addition to the medical curriculum is not only realistic, but essential. One may object on the grounds that teaching evolution at the total expense of problem-based learning is not the optimal solution (a combination probably is most effective). Nevertheless, I believe that such an addition of evolutionary biology is a goal for the future. The major problem is how to make this addition at a time when the various curricula already seem supersaturated with information. I argue that a first step toward such a goal can be accomplished through an ecological focus in a broad sense.

\section{ECOLOGICAL HEALTH THEORY}

Merete Steen, two other physicians and I worked from 1994 to 1996 on a textbook called "Ecological Health Theory" (Solli et al. 1996) in which the evolutionary perspective is integrated into a common framework. We first decided that the most effective strategy for the future was to write a textbook aimed at a "young" audience rather than for the medical establishment. By introducing novel ideas and a fresh perspective to students at the outset of their education, we hoped to contribute to a new generation of physicians and health care personnel which was better prepared for a future in the health profession.

From our point of view, several important approaches are absent from today's education in these fields: the evolutionary perspective, environmental medicine on both a local and global (Fugelli 1993) scale, a stressing of the importance of communication in the clinical setting (between the practitioner and patient) as well as how we cope with the increasing environmental problems. All this can be integrated into a coherent framwork when applying an ecological perspective.

Although ecology includes several research traditions and definitions (Mysterud \& Mysterud 1994), the one which is best suited for humans in a medical setting is one which focuses on the organismenvironment interaction. This is, for example, the perspective used by medical anthropologists with an ecological approach (McElroy \& Townsend 1989). By defining ecology as the "the study of the relation of organisms or groups of organisms to their environment" (Odum 1971, p. 3), it is possible to study the interaction between humans and the physical-chemical environment (e.g. environmental medicine), between humans and the living (biotic) environment (e.g. the study of infectious diseases) and between humans and the social environment (e.g. social medicine and various social sciences) within the same framework. And when applying the human-environment interactions over time, one in essence applies the evolutionary approach. Darwinian medicine is thus at the core of the ecological health theory as we have presented it as one chapter after the introduction and whenever relevant throughout the book (Solli et al. 1996). But in addition to using the concept of "adaptation" in the traditional Darwinian sense (having a genetic basis), we also use adaptation in a broader sense. This implies following McElroy \& Townsend's (1989) focus on cultural adaptation. When our biochemical machinery is insufficient to cope with features of the environment, cultural adaptation may be the solution. This could for instance imply developing culinary practices which enable the ingestion of foods which otherwise would be unhealthy or even fatal (Katz 1990). Another cultural adaptation is to develop technology to cope with new environmental hazards (like PCBs, DDT and part of the electromagnetic spectrum) about which our old sense apparatus, better adapted to a Stone Age environment, does not warn us.

So far, our impression is that most students consider the human-environment interaction to be a useful framework for organizing the various details of their studies, within both medicine and nursing.

The book Ecological Health Theory (Solli et al. 1996) is already in the curriculum at two of the four Norwegian medical schools and at some nursing schools. The chapter on Darwinian medicine will probably be addressed in 1-2 hours of teaching. The book, and particularly the evolutionary section, is also being considered for the curriculum at one school of alternative medicine (focusing on nutrition and "ecological medicine").

\section{OTHER RECENT DEVELOPMENTS}

In the following, I briefly describe four other areas in Norway where an evolutionary approach to medicine is presented, used or developed.

\section{New standard reference for general practice}

General practice is recognized as a medical speciality in Norway (Westin \& Østensen 1987), and two years ago a new comprehensive standard reference for this specialist education was published (Getz \& Westin 1996). One part of the book is called "Medicine in a wider perspective", and it contains a chapter called "Ecology and general practice", which presents Darwinian medicine, describing it as an exciting field, citing among others Nesse \& Williams (1995) and various overview papers from Tidsskr Nor Lageforen.

\section{The Paleolithic Prescription and losing weight}

The "Paleolithic Prescription" is "a general plan for recapturing certain features of our ancestors' lives and for integrating these elements with our own life-style" (Eaton et al. 1988a). It contains various hypotheses about what kind of diet and physical exercise is "natural" for humans by estimating how life in the Stone Age may have been. Another Norwegian physician, Stig Bruset, has brought "the Paleolithic 
Prescription" into a clinical setting in connection with weight loss by obese patients. Actually, this was done on a weekly television program ("Helse-refleks") on the national channel which presented the "Stone Age cure" while following one particular obese person's weight loss. It was done in a very humorous way, and the therapy worked well. Bruset, together with his now significantly slimmer patient, then wrote about the Stone Age way of losing weight in a readable book which is accessible to a large audience (Bruset \& Henriksen 1996).

\section{The Paleolithic Prescription and allergy patients}

Clinical use of "the Paleolithic Prescription" is applied at a private clinic ("Balderklinikken") in Oslo. The physicians use a "Stone Age diet" for patients suspected of being allergic to or intolerant of certain foods. The patients are placed on a diet consisting of unprocessed food without grains, egg and milk products for a certain period. The philosophy behind this diet is that the chances are minimal of developing allergies and intolerance towards foods produced and prepared as before the agricultural revolution, because humans may be better genetically adapted to such foods. When the patients have been on a Stone Age diet for about 10 days, the suspected foods (allergens) (e.g. milk and wheat) are introduced, one by one.

No one in the USA is known to use "the Paleolithic Prescription" in the way done at Balderklinikken (S. Boyd Eaton, personal correspondence 1994).

\section{Medical Yearbook 1998}

I was invited to write an overview paper for the Medical Yearbook 1998 (a medical yearbook for Norway,
Sweden and Denmark). This is another promising sign that physicians have begun to take an evolutionary approach seriously. Further, the paper was laced first in the book.

\section{CONCLUSION}

Ever since Darwinian medicine was synthesized by Williams and Nesse in 1991, the approach has been exposed to a steadily widening Norwegian audience, particularly of physicians, in various journals, mainly Tidsskr Nor Lageforen. Several physicians have become enthusiastic about the approach. It has recently been integrated into a Norwegian textbook within the organism-environment interaction framework offering a unifying and exciting perspective (Solli et al. 1996), and briefly presented in a book for the continued education of physicians in the specialty of general practice (Getz \& Westin 1996). Time has come to integrate Darwinian medicine more systematically into the medical and health care curricula in Norway. Nesse \& Williams' (1997) and Nesse's (in prep.) goal of implementing evolutionary biology as a basic science for medicine may not be too distant.

\section{ACKNOWLEDGEMENTS}

The article is based on a lecture given at The Ninth Annual Meeting of Human Behavior and Evolution Society at University of Arizona, Tucson, AZ, USA, June 4-June 8, 1997. It benefited from comments of Morten Finckenhagen, Trond Peder Flaten, Ivar Mysterud, Hans Magnus Solli, Merete Steen and Jerry Thomas Warren. Per A. Brodal, Olbjørn Klepp and Steinar Westin provided valuable knowledge about local conditions. Astrid Rangnes Bråten at Ad Notam Gyldendal provided background material.

\section{REFERENCES}

Bruset S, Henriksen J. Slank på steinaldermat [Slim on Stone Age Food]. Oslo: Gyldendal, 1996.

Eaton SB, Shostak M, Konner, M. The Paleolithic Prescription: A Program of Diet \& Exercise and a Design for Living. New York: Harper \& Row, 1988a.

Eaton SB, Konner M, Shostak M. Stone agers in the fast lane: chronic degenerative diseases in evolutionary perspective. Am J Med 1988b; 84: 739-49.

Eaton SB, Pike MC, Short RV, et al. Womens reproductive cancers in evolutionary context. Q Rev Biol 1994; 69: 353-67.

Ewald PW. Evolution of Infectious Disease. New York: Oxford University Press, 1994.

Fugelli P. In search of a global social medicine. Forum for Development Studies 1993 (1): 101-8.

Getz L, Westin S. Håndbok for spesialistutdanningen i allmennmedisin [Handbook for Specialist Education in General Practice]. Oslo: Ad Notam Gyldendal, 1996. English summary.

Gould SJ. Wonderful Life: The Burgess Shale and the Nature of History. New York: Norton, 1989.

Haig D. Genomic imprinting and the theory of parent-offspring conflict. Semin Devel Biol 1992; 3: 153-60.

Haig D. Genetic conflict in human pregnancy. Q Rev Biol 1993; 68: 495-532.

Haig D. Cohabitation and pregnancy-induced hypertension. Lancet 1994; 344: 1633-4.

Katz SH. An evolutionary theory of cuisine. Human Nature 1990; 1: 233-59.

Kluger MJ. The adaptive value of fever. In: Mackowiak P, ed. Fever: Basic Mechanisms and Management. New York: Raven Press, 1991: 105-24.

Mayr E. How to carry out the adaptationist program? American Naturalist 1983; 121: 324-34.

McElroy A, Townsend PK. Medical Anthropology in Ecological Perspective. London: Westview Press, 1989.

Mysterud I, Mysterud I. Reviving the ghost of broad ecology. J Soc Evol Syst 1994; 17: 167-95. 
Nesse R. The evolution of medical education: the missing basic science. In prep.

Nesse RM, Williams GC. Why We Get Sick: The New Science of Darwinian Medicine. New York: Times Books, 1995 (British version: Evolution and Healing: The New Science of Darwinian Medicine. London: The Orion Publishing Group, 1995).

Nesse R, Williams G. Evolutionary biology in the medical curriculum: What every physician should know. BioScience 1997; 47: 664-6.

Odum EP. Fundamentals of Ecology (3. ed.). Philadelphia: Saunders, 1971.

Profet M. The evolution of pregnancy sickness as protection to the embryo against Pleistocene teratogens. Evol Theory 1988; 8: 177-90.

Profet M. The function of allergy: immunological defense against toxins. Q Rev Biol 1991; 66: 23-62.

Profet M. 1992. Pregnancy sickness as adaptation: a deterrent to maternal ingestion of teratogens. In: Barkow J, Cosmides L, Tooby J, eds. The Adapted Mind: Evolutionary Psychology and the Generation of Culture. New York: Oxford University Press, 1992: 327-65.

Profet M. Menstruation as a defense against pathogens transported by sperm. Q Rev Biol 1993; 68: 335-81.

Profet M. Protecting Your Baby-to-be: Preventing Birth Defects in the First Trimester. Reading, MA: AddisonWesley, 1995.

Solli HM, Mysterud I, Steen M, Fugelli P. Økologisk helselaere: En innføring for medisin- og helsefagstudenter [Ecological Health Theory: An Introduction for Medical and Health Care Students]. Oslo: Ad Notam Gyldendal, 1996.

Steen M. Om kropp og miljø og legens øyne [About body and environment and the eyes of the physician]. Tidsskr Nor Lageforen 1993; 113: 2440.

Strassmann BI. The evolution of endometrial cycles and menstruation. Q Rev Biol 1996; 71: 181-220.

Sulloway FJ. Born to Rebel: Birth Order, Family Dynamics, and Creative Lives. New York: Pantheon Books, 1996.

Toft CA, Aeschlimann A, Bolis L, eds. Parasite-Host Associations: Coexistence or Conflict? Oxford: Oxford University Press, 1991.

Westin S, Østensen AI. General practice recognized as a speciality in Norway. Scand J Prim Health Care 1987; 5: $60-1$.

Williams GC, Nesse RM. The dawn of Darwinian medicine. Q Rev Biol 1991; 66: 1-22.

\section{APPENDIX: LITERATURE IN NORWEGIAN ON DARWINIAN MEDICINE}

Below is an overview of what, to my knowledge, has been written about Darwinian medicine in Norwegian. Material about pathogen resistance to antibiotics has been excluded.

\section{Books}

Bruset S, Henriksen J. Slank på steinaldermat [Slim on Stone Age Food]. Oslo: Gyldendal, 1996.

Getz L, Westin S. Håndbok for spesialistutdanningen i allmennmedisin [Handbook for Specialist Education in General Practice]. Oslo: Ad Notam Gyldendal, 1996. 482 pp (English summary, one page devoted to Darwinian medicine).

Solli HM, Mysterud I, Steen M, Fugelli P. Økologisk helseloere: En innforing for medisin- og helsefagstudenter [Ecological Health Theory: An Introduction for Medical and Health Care Students]. Oslo: Ad Notam Gyldendal, 1996. 314 pp (One chapter devoted to Darwinian medicine).

\section{Articles}

Borch-Iohnsen B, Sellevold BJ. Hva spiste kvinner i steinalderen og hva spiser de i dag? Jern i kosten da og nå [What did the women of the Stone Age eat and what do they eat today? Iron in the diet, past and present]. Tidsskr Nor Loegeforen 1998; 118: 1590-1.

Mysterud I. Medisinsk økologi - fokus på et helhetlig helsebegrep [Medical ecology - focus on a holistic health concept]. Tidsskr Nor Lageforen 1992; 112: 812-5.

Mysterud I, Mysterud I. Økologi, evolusjon og medisin [Ecology, evolution and medicine]. Humanekologi 1992; 11 (2/3): 6-39 (English summary).

Mysterud I. Økologi og medisin [Ecology and medicine]. Skoleforum 1992;91 (14): 48-52.

Mysterud I. Økologi og medisin [Ecology and medicine]. Samtiden 1993; (3): 76-80.

Mysterud I. Darwinian medicine. Image (Corporate magazine from Hafslund Nycomed) 1993; (2): 8-10 (both Norwegian and English versions).

Mysterud I. Soma og psyke i et darwinistisk perspektiv [Soma and psyche in a Darwinian perspective]. Tidsskr Nor Lageforen 1993; 113: 3058-62.

Mysterud I. Darwins ufullendte revolusjon: Noen inntrykk fra London-konferansen 1993 i human atferdsøkologi [Darwin's unfinished revolution: Some impressions from the London conference 1993 in human behavioural ecology]. Humanekologi 1994; 13 (1-2): 64-71.

Mysterud I. Profet om allergier, svangerskapsubehag og menstruasjon [Profet on allergies, pregnancy sickness and menstruation]. Tidsskr Nor Lageforen 1994; 114: 1634-6.

Mysterud I. Utvidelse av det evolusjonære perspektivet på mennesket [Expansion of the evolutionary perspective on humans]. Tidsskr Nor Lageforen 1994; 114: 2866-7. 
Mysterud I. Medisin i darwinistisk perspektiv [Medicine in Darwinian perspective]. Naturen 1995; 119 (2): 64-8.

Mysterud I. Fruktbare koblinger mellom økologi og medisin [Fertile links between ecology and medicine]. Tidsskr Nor Loegeforen 1995; 115: 1262-5.

Mysterud I. Darwins ufullendte revolusjon [Darwin's unfinished revolution]. Samtiden 1995; (3): 69-77.

Mysterud I. Gener, atferd og sykdom: En skeptikers syn på genkartlegging og genterapi [Genes, behavior and disease: A skeptic's view of gene mapping and gene therapy]. Tidsskr Nor Lageforen 1995; 115: 2114-9.

Mysterud I. Evolusjon, svangerskap og fødselsrekkefølge [Evolution, pregnancy and birth order]. Tidsskr Nor Loegeforen 1996; 116: $1002-4$

Mysterud I. Darwinistisk medisin I: Anvendelse av tilpasningsprogrammet i medisinen [Darwinian medicine I: Application of the adaptationist program in medicine]. Biolog 1997; 15 (3): 2-14.

Mysterud I. Darwinistisk medisin II: Gamle gener og nytt miljø [Darwinian medicine II: Old genes and new environment]. Biolog 1997; 15 (4): 2-7.

Mysterud I. Darwinistisk medisin: Søken etter evolusjonære funksjonsforklaringer i medisinen [Darwinian medicine: search for evolutionary functional explanations in medicine]. In: Medicinsk Arbog 1998. Copenhagen: Munksgaard, 1998: 9-18.

Mysterud I. Evolusjonsforskere i møte blant kaktus og stekende hete [A meeting of evolutionary researchers among cactus and burning heat]. Tidsskrift for Norsk Psykologforening 1998; 35: 345-9.

Mysterud I, Mysterud I, Slagsvold T. Kurs om evolusjon og mennesker ved Biologisk institutt, UiO. [Course in evolution and humans at Department of Biology, UiO] Utposten 1997; 26 (1): 38-41.

Poleszynski DV, Mysterud I. Evolusjon, medisin og kosthold [Evolution, medicine and diet]. Ernceringsfysiologen 1995 (2): 4-29.

Steen M. Om kropp og miljø og legens øyne [About body and environment and the eyes of the physician]. Tidsskr Nor Lageforen 1993; 113: 2440.

\section{Contributions in dictionaries/overview books}

Mysterud I. Svangerskapsubehag [Pregnancy sickness]. In: Poleszynski DV (Norwegian editor). Riktig mat - bedre helse [Foods that Harm, Foods that Heal]. Oslo: Det Beste A/S, 1996: 361, 364.

Mysterud I. Steinalderdietten [The Paleolithic diet]. In: Poleszynski DV (Norwegian editor). Riktig mat - bedre helse [Foods that Harm, Foods that Heal]. Oslo: Det Beste A/S, 1996: 343-4.

\section{Interviews}

Mysterud I. Vi intervjuer Randolph Nesse - vidsynt darwinistisk psykiater [We interview Randolph Nesse - foresighted Darwinian psychiatrist]. Tidsskr Nor Laegeforen 1993; 113: 2148-50.

Mysterud I. Vi intervjuer S. Boyd Eaton. Moderne kosthold og helse sett gjennom steinalderbriller. [We interview S. Boyd Eaton. Modern diet and health seen through Stone Age glasses]. Tidsskr Nor Lageforen 1994; 114: 1220-1.

Mysterud I. Vyer for darwinistisk medisin. Randolph Nesse intervjuet av Iver Mysterud. [Visions for Darwinian medicine. Randolph Nesse interviewed by Iver Mysterud] Utposten 1997; 26 (6): 234-5.

\section{Debates}

Børresen B. Hvilken steinalder? [What stone age?] Tidsskr Nor Lageforen 1994; 114: 1864.

Konner M, Eaton SB, Mysterud I. Hvilken steinalder? [What stone age?] Tidsskr Nor Lageforen 1994; 114: 2765.

Børresen B. Hvilken steinalder? [What stone age?] Tidsskr Nor Lageforen 1994; 114: 3501.

\section{Book reviews}

Mysterud I. Sameksistens eller konflikt mellom parasitter og verter? [Coexistence or conflict between parasites and hosts?] (review of Toft CA, Aeschlimann A, Bolis L, eds. Parasite-Host Associations: Coexistence or Conflict? Oxford: Oxford University Press, 1991). Tidsskr Nor Laegeforen 1994; 114: 1277, 1279, 1281.

Mysterud I. Medisinsk økologi [Medical ecology]. (review of Mascie-Taylor CGN, Lasker GW, eds. Applications of Biological Anthropology to Human Affairs. Cambridge: Cambridge University Press, 1991). Tidsskr Nor Lageforen 1995; 115: 1035, $1037,1039,1041$.

Mysterud I. "Bibel" om darwinistisk medisin ["Bible" on Darwinian medicine]. (review of Nesse RM, Williams GC. Why We Get Sick: The New Science of Darwinian Medicine. New York: Times Books, 1995). Tidsskr Nor Lageforen 1995; 115: $2142-3$.

Mysterud I. Svangerskapets forste tredel [The first trimester of pregnancy]. (review of Profet M. Protecting Your Baby-to-be: Preventing Birth Defects in the First Trimester. Reading, MA: Addison-Wesley, 1995). Tidsskr Nor Laegeforen 1996; 116: 2289, 2291.

Mysterud I. Infeksjoner i evolusjonært perspektiv [Infections in evolutionary perspective]. (review of Ewald, P.W. 1994. Evolution of Infectious Disease. Oxford: Oxford Univ. Press). Tidsskr Nor Loegeforen 1996; 116: 2458-9.

Mysterud I. Slank på steinaldervis [Slim the Stone Age way]. (review of Bruset S, Henriksen J. Slank på steinaldermat. Oslo: Gyldendal, 1996). Biolog 1997; 15 (4): 42-3.

Nylenna M. Nye koster veier mest [New brooms weigh most]. (review of Bruset S, Henriksen J. Slank på steinaldermat. Oslo: Gyldendal, 1996). Tidsskr Nor Lageforen 1997; 117: 88.

\section{Smaller contributions in newspapers}

Grinde B. Genteknologi og det lille våpenkappløpet [Gene technology and the small arms race]. Aftenposten 24.04.96.

Mysterud I. Helse i et annet perspektiv [Health in a different perspective]. Klassekampen 01.02.95.

Mysterud I. Dans med Darwin, Hernes! [Dance with Darwin, Hernes!] Arbeiderbladet 26.02.96.

\section{Presentations in weeklies (popular magazines)}

Thuesen NP. Med steinalderen i kroppen [With the Stone Age in the body]. Vi Menn 1993 (26): 44-6. 